\title{
Using Importance-Performance Analysis in Evaluating Institutions of Higher Education: A Case Study
}

\author{
Fátima Silva \\ School of Technology and Management \\ Polytechnic Institute of Bragança, IPB \\ Bragança, Portugal \\ fsilva@ipb.pt
}

\begin{abstract}
A large number of management quality models that are universally applied in the business environment, have been adapted and used in the education sector. The aim of this paper is to assess the quality attributes of higher education from different perspectives, namely from that of School of Technology and Management students, applying the Importance-Performance Analysis. The results show that students are satisfied with their institution.
\end{abstract}

Keywords: importance-performance analysis; higher education; student satisfaction; service quality; expected quality.

\section{INTRODUCTION}

Quality has become an important subject of discussion amongst Higher Education Institutions, and has been extensively studied in recent years. One of the main ways to retain students is to determine if they are satisfied with the institution's performance and how it compares to what they expected when they first arrived at the institution, and during their attendance.

Nowadays one of the appropriate techniques to measure service quality in education is the Importance-Performance Analysis (IPA) tool.

The main reason for this study is to increase the literature available in management service quality in higher education. This will be completed through assessing and comparing the perception of undergraduate students at the School of Technology and Management (ESTiG) of the Polytechnic Institute of Bragança (Portugal).

This paper is organized as follow: Section 2 reviews importance-performance analysis; Section 3 presents a case study for evaluating and comparing the attributes of the ESTiG institution; and finally, the conclusions are described in Section 4.

\section{IMPORTANCE-PERFORMANCE ANALYSIS}

The Importance-Performance Analysis first proposed by Martilla and James, in 1977, is a tool to enable management to identify the strengths and weaknesses of a company [1], and has been applied to different areas of Services Marketing, thus becoming a good approach to measure customer/user satisfaction [2].

IPA is a part of marketing research techniques that involves the analysis of customers attitudes towards product/service attributes and direct quality-based perceptions for marketing strategies [1, 3, 4]. Additionally, IPA is able to identify the most important attributes from a

\author{
Paula Fernandes \\ NECE- Research Unit in Business Sciences, UBI \\ Polytechnic Institute of Bragança, IPB \\ Bragança, Portugal \\ pof@ipb.pt
}

customer's point of view, with the highest impact on customer satisfaction and the low performance attributes requiring immediate improvements [5]. Using both importance and performance assigned by customers/users to all relevant aspects of a given service and the perceived performance of the institution in providing the service, a matrix or graph with four quadrants is generated $[6,8,10]$.

The IPA consists of a pair of coordinate axis where the 'importance' (y-axis) and the 'performance' (x-axis) of the different elements involved in the service are compared (Fig. 1). Each of the quadrants combines the importance and the performance assigned by customers/users to a specific element of the service and possesses a different value in terms of management $[2,7,12]$.

The four quadrants in importance-performance analysis are characterized as [6, pg. 78]:

“- A. Concentrate here - high importance, low performance: requires immediate attention for improvement and are major weaknesses;

- B. Keep up with the good work: high importance, high performance, indicates opportunities for achieving or maintaining competitive advantage and are major strengths; - C. Low priority - low importance, low performance: are minor weaknesses and do not require additional effort;

- D. Possible overkill - low importance, high performance: indicates that business resources committed to these attributes would be overkill and should be deployed elsewhere".

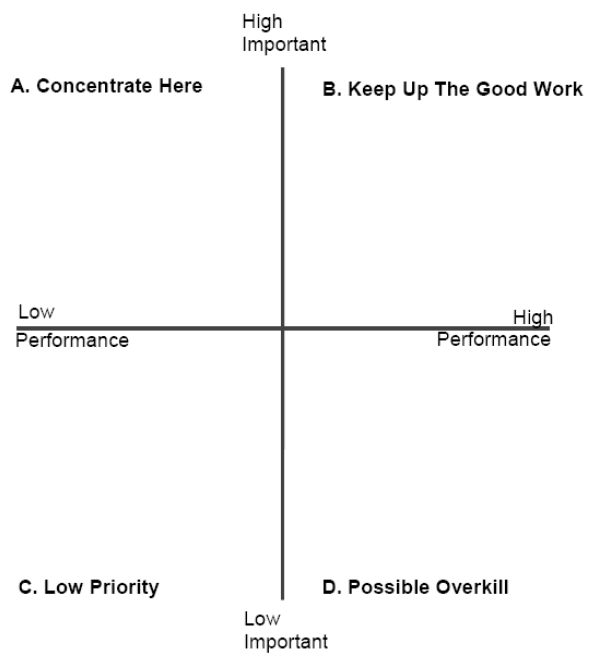

Figure 1. Importance-Performance Matrix [Adapted from 6, pg. 78] 
A complementing questionnaire is essential to determine the level of importance assigned to each attribute as well as respondents (customers/students) perceptions of the actual performance attribute $[6,9,11,12]$.

\section{IMPORTANCE-PERFORMANCE ANALYSIS: ESTIG CASE STUDY}

\section{A. Methodology}

The data for this study was collected in classroom via a questionnaire to students who attend the undergraduate programs at the School of Technology and Management of Polytechnic Institute of Bragança, located in the town of Bragança, Portugal.

The instrument used was divided into two sections; Section I collected personal information from the student, and Section II refers to students' perceptions of the importance and performance of key attributes and their satisfaction relating to these attributes. The attributes under consideration are: Quality of General Aspects, Quality of the Library, Quality of Computer Laboratory Facilities, Quality of Academic Services, Quality of Teaching Aspects, Quality of Undergraduate Programs, and Quality of External Relations.

The survey was conducted during April and May 2010, in the $2^{\text {nd }}$ semester of the 2009/2010 academic year. A total of 695 valid questionnaires were received, which represents $34 \%$ of the total student population (2031 students). The sample size resulted in a sampling error of $3.7 \%$, assuming a $95 \%$ confidence level.

\section{B. Results and Discussion}

In this point we intend to discuss the main conclusion of this study.

Table I lists some of the characteristics of the respondents. The original sample consisted in 695 students, $46 \%$ female and $54 \%$ male, the majority is between 20 and 25 years old and coming from undergraduate programs, 57.8\% from Engineering Sciences and 42.2\% from Management Sciences.

TABLE I. GENERAL CHARACTERISTICS OF SAMPLED STUdENTS $(n=695)$.

\begin{tabular}{lcc}
\hline Variable & No. & \% \\
\hline Gender & & \\
$\quad$ Female & 320 & $46 \%$ \\
$\quad$ Male & 375 & $54 \%$ \\
Age & & \\
$\quad<20$ years old & 152 & $21.9 \%$ \\
20-25 years old & 466 & $67.0 \%$ \\
26-30 years old & 49 & $7.1 \%$ \\
$\quad>30$ years old & 28 & $4.0 \%$ \\
Study Areas & & \\
$\quad$ Engineering Sciences & 402 & $57.8 \%$ \\
$\quad$ Management Sciences & 293 & $42.2 \%$ \\
\hline
\end{tabular}

TABLE II. IMPORTANCE-PERFORMANCE RATINGS FOR ESTIG.

\begin{tabular}{|c|c|c|c|}
\hline $\begin{array}{l}\text { Attribute } \\
\text { Code }\end{array}$ & Attribute Description & $\begin{array}{c}\text { Mean } \\
\text { Importance } \\
\text { Rating }^{\mathrm{a}} \\
\end{array}$ & $\begin{array}{c}\text { Mean } \\
\text { Performance } \\
\text { Rating }^{\mathbf{b}} \\
\end{array}$ \\
\hline$[\mathrm{A}]$ & Quality of General Aspects & 3.97 & 3.60 \\
\hline$[\mathrm{B}]$ & Quality of the Library & 4.37 & 3.50 \\
\hline$[\mathrm{C}]$ & $\begin{array}{l}\text { Quality of Computer Laboratory } \\
\text { Facilities }\end{array}$ & 4.32 & 3.45 \\
\hline$[\mathrm{D}]$ & Quality of Social Services & 4.29 & 3.45 \\
\hline$[\mathrm{E}]$ & Quality of Academic Services & 4.27 & 3.14 \\
\hline$[\mathrm{F}]$ & Quality of Teaching Aspects & 4.45 & 3.52 \\
\hline$[\mathrm{G}]$ & $\begin{array}{l}\text { Quality of Undergraduate } \\
\text { Programs }\end{array}$ & 4.62 & 3.80 \\
\hline \multirow[t]{2}{*}[\mathrm{H}]{} & Quality of External Relations & 4.41 & 3.68 \\
\hline & Total Average & 4.34 & 3.52 \\
\hline${ }^{\mathrm{a}}$ Rati & btained from a five-point Likert scale rangi & om "Very unim & $\begin{array}{l}\text { ant" (1) to "Very } \\
\text { important" (5). }\end{array}$ \\
\hline
\end{tabular}

From the above table it is possible to learn the mean rating for both I-P scale, and conclude that students are quite satisfied with the performance (mean of 3.52), but results also convey a higher importance to each of the items under analysis, registering a mean of 4.34 .

Once the mean scores for each pair of importance and performance features are calculated, they are plotted on a two-dimensional, four quadrant matrix (see Fig. 2). Fig. 2 gives a graphic representation of the features compiled in Table II.

In Fig. 2 we can see a more detailed analysis of attributes. Thus, it can be noted that all the attributes studied are positioned in Quadrant B - "Keep up with the good work", which correspond to attributes with high performance assessments, and are also judged as high in importance by students, which means the level of service provided in those attributes is satisfactory. These issues are of extreme importance to students and are aspects where ESTiG has a good performance, so it should keep up the standards as a way to better correspond to their needs.

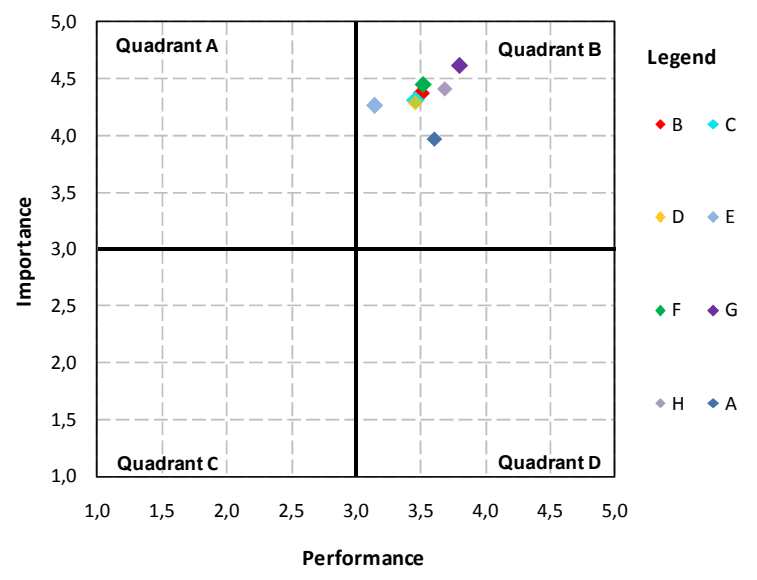

Figure 2. Importance-Performance Analysis. 
ESTiG must focus in Quality of Academic Services, because this is the area that is closer to Quadrant A. Given the importance of these aspects it will be in this area that ESTiG must be aware and concentrate efforts in order to better correspond to the needs of their students. Fig. 2 also shows the area of lower importance to students but, at the same time, ESTiG has a reasonable performance relatively to General Aspects in their opinion. This attribute incorporates aspects related to clean and modern school, sports and cultural activities and student associations.

On the other hand the area of upmost importance to students is the Quality of Undergraduate Programs (see Fig.2). This attribute measures aspects related to study plans and their updated contents, and Undergraduate Programs provide more career opportunities in the job market.

We can also observe, in Table II, attributes like Quality of Teaching Aspects and Quality of External Relations registering high values in both counts. The first one includes the following aspects: teachers' friendliness, personalized attention, easy communication with teachers, teachers explaining with clarity and precision the contents of subjects, teachers with scientific ability to answer any question, reasonable assessment, and bibliography recommendation. The second one incorporate questions like: help in obtaining traineeship, exchange programs for students with foreign countries, and internet access.

From the results we can draw conclusions regarding importance and performance measures. To ESTiG's board it will provide a richer understanding of students reactions and perceptions about services offered by this institution. From the IPA, the board will not only know which attributes require immediate attention, but also, why they require this attention.

\section{CONCLUSIONS AND RECOMMENDATIONS}

Importance-Performance Analysis was introduced by Martilla and James in 1977 as a method for developing and analysing business strategies. Since its origins, the importance-performance analysis has been applied to different areas.

Importance-Performance Analysis is a helpful tool in evaluating Institutions of Higher Education, because through this process we can identify strengths and weaknesses. After identifying these factors we can formulate strategies to enhance strengths and eliminate weaknesses.

The results of this study suggest that students are generally satisfied with the Institution (ESTIG). This outcome is supported by the high importance and performance ratings noted in the quadrant "Keep up with the good work" - maintenance reinforcement area. Students were mainly satisfied with Quality of Undergraduate Programs, Quality of Teaching Aspects and Quality of External Relations.

The generalization of these results should not, however, be overstated. It would be interesting to look at the
Institution's management and employers' perceptions in terms of education quality attributes and how these differences affect the types of policy and management practices.

Further investigation into this topic will provide a basis for policy and quality improvement plans undertaken by the School of Technology and Management of the Polytechnic Institute of Bragança, Portugal.

\section{ACKNOWLEDGMENTS}

This work has been supported by the School of Technology and Management of the Polytechnic Institute of Bragança (Portugal). The authors would like to thank the students who answered the questionnaires and the teachers at ESTiG for allowing time in their classes for carrying out the investigation. We would also like to thank ESTiG's Principal for authorizing the use of the questionnaires in the Institution.

\section{REFERENCES}

[1] H. Wu, Y. Tang and J. Shyu, "A case of applying importance-performance analysis in identifying key success factors to develop marketing strategies", in Journal Quality and Quantity, 2009, ISSN 0033-5177 (Print) 1573-7845 (Online).

[2] F. Go and W. Zhang, "Applying importance-performance analysis to Beijing as an international meeting destination", in Journal of Travel Research, 2008, n. ${ }^{\circ} 35:$ 1, pp.42-49.

[3] R. Lewis, "Importance-Performance Analysis", in Australasian Journal of Engineering Education, 2004, pp.1-8.

[4] S. Sampson and M. Showalter, "The Performance-Importance Response Function: Observations and Implications", in The Service Industries Journal, 1999, No.19:3, pp.1 - 25.

[5] A. Rial, J. Rial, J. Varela and E. Real, "An application of importance-performance analysis (IPA) to the management of sport centres", in Managing Leisure, 2008, No.13, pp. 179-188.

[6] Martilla and J. James, "Importance-performance analysis", in Journal of Marketing, 1977, No.41, pp. 77-79.

[7] F. Guadagnolo, "The Importance-Performance Analysis: An evaluation and marketing tool", in Journal of Park and Recreation Administration, 1985, No.3, pp.13-22.

[8] D. Bacon, "A comparison of approaches to importance-performance analysis", in International Journal of Market Research, 2003, No.45:1, pp.55-71.

[9] H. Amin and A. Khan, "Acquiring Knowledge for Evaluation of Teachers' Performance in Higher Education - using a Questionnaire", in International Journal of Computer Science and Informatics Security, 2009, Vol. 2, No. 1.

[10] M. Joseph and B. Joseph, "Employers' Perceptions of Service Quality in Higher Education", in Journal of Marketing for Higher Education, 1997, No. 8:2, pp.1-13.

[11] S. Erevelles, S. Srinivasan and S. Rangel, "Consumer Satisfaction for Internet Service Providers: An Analysis of Underlying Processes", in Information Technology and Management, 2003, No.4, pp.69-89.

[12] J. Abalo, J. Varela and V. Manzano, "Importance values for Importance-Performance Analysis: A formula for spreading out values derived from preference rankings", in Journal of Business Research, 2007, No.60, pp.115-121. 